\section{Designs upon Postage Stamps}

SLIGHT changes in colour and design have just been made in certain postage stamps for Great Britain, printed for the first time by lithographic process; now the United States of America has notified the appearance of new issues. These are to bear striking scenes from ten of America's National Park areas, such as Yosemite's El Capitan on the one cent stamp, the Grand Canyon on the two cent, Old Faithful Geyser on the five cent, Crater Lake on the seven cent, and, an interesting breakaway from tradition, a prehistoric apartment from the great Mesa Verde 'cliff palace' on the four cent. There is a great deal to be said for the reproduction of features which give a new beauty and interest to each stamp, and at the same time spread a knowledge of the great natural monuments of the country open to traveller and naturalist.

\section{Dissemination of the Brazil Nut}

IN his article on the germination of seeds with stony endocarps, printed in Nature of June 16, Sir Arthur Hill referred to the difficulties of germination in the Brazil nut. Mr. C. Jinarajadasa writes from Belém, Para, that he mentioned this to Dr. Carlos Estevão, director of the Goeldi Museum, Para, Brazil, who stated that two varieties of agouti (Dasyprocta fulginosa, Wagl., and Aguti-Aguti, L.) are able to break up the hard shell of the Brazil nut with their sharp teeth. After eating a few nuts they bury the remainder in various places, and in this manner Brazil nut seeds are spread and germinate without interference with one another.

\section{New Analytical Balance}

WE have had an opportunity of examining the "New Empire" Analytical Balance made by Messrs. Baird and Tatlock (London) Ltd., 14-17 Cross Street, Hatton Gardens, London, E.C.I, and find that it has a number of interesting features. The fittings which are usually of brass are made in stainless steel and other parts are chromium plated. The beam is finished black, which is claimed to be fume and scratch proof, and the top edge is bevelled so that the rider can be accurately placed. The rider seale is white on black, and is easily read. The side and front doors are large and open easily, and the pan hangers are widely spaced so that large flasks may be weighed. Loose bakelite pans are supplied to fit over the metal pans and we found that these were adjusted in weight within two milligrams. The lifting mechanism worked very smoothly, and the period was reasonably short. The sensibility was very good both with small and heavy loads, and the balance is suitable for all accurate work requiring four places of decimals of a gram. The finish of the whole balance is very good, and its appearance compares favourably with that of much more expensive instruments. The agate knife edges and planes are sensibly mounted, and the robust character of the balance makes it very suitable for use by students. The boxes of weights supplied for use with the balance are of gold-plated pieces with fractions in nickel and aluminium, the whole being enclosed in a bakelite block and case which will not warp, the top of the block being covered with velvet. We formed a very favourable opinion of the balance and weights, which represent exceptionally good value for the price charged, and should make a wide appeal to various types of users.

\section{Announcements}

Prof. Jacos G. LtPman, dean of agriculture in Rutgers University and director of the New Jersey Agricultural Experiment Station, has been awarded the Chandler Medal of Columbia University for 1934, for his work in agricultural chemistry. The Chandler Medal is awarded annually by Columbia University for "conspicuous work in the field of chemistry". Prof. Lipman was president of the First International Congress of Soil Science and is the founder and editor of Soil Science.

THE Third International Locust Conference will meet in London on September 11 in the Lord Chairman of Committees' Room, House of Lords, under the presidency of Sir John Chancellor. His Majesty's Government in the United Kingdom will be represented by Sir Guy A. K. Marshall, director of the Imperial Institute of Entomology; Mr. B. P. Uvarov, senior assistant, Imperial Institute of Entomology; Mr. H. B. Johnston, chief locust investigator of the Institute; Mr. G. F. Seel of the Colonial Office; and Mr. M. C. Mossop, nominated by the Government of Southern Rhodesia. The meetings will be open to the public. Cards of admission may be obtained from Mr. Francis Hemming, Secretary-General to the Conference, 2, Whitehall Gardens, S.W.l.

Applications are invited for the following appointments, on or before the dates mentioned:-A technical officer at the Admiralty Technical PoolThe Secretary of the Admiralty (C.E. Branch), Whitehall, London, S.W.1 (Sept. 12). An assistant agricultural organiser to the Nottinghamshire Education Committee-The Director of Education, Shire Hall, Nottingham (Sept. 12). An assistant at the Fuel Research Station, East Greenwich-The Establishment Officer, Department of Scientific and Industrial Research, 16, Old Queen Street, Westminster, S.W.1 (Sept. 15). A chemist in the Department of the Government Chemist-The Government Chemist, Clement's Inn Passage, Strand, W.C.2 (Sept. 15). Assistant civil engineers in the Civil Engineer-in-Chief's Department, Admiralty and H.M. Naval Establishments-The Civil Engineer-in-Chief, Admiralty, London, S.W.1 (Sept. 15). An assistant plant pathologist in the Department of Agriculture and Lands, Salisbury, Southern Rhodesia-The Official Secretary, Office of the High Commissioner for Southern Rhodesia, Crown House, Aldwych, London, W.C.2 (Sept. 15). A superintendent of forests in the Department of Agriculture and Forests, Sudan Government-The Controller, Sudan Government, London Office, Wellington House, Buckingham Gate, S.W.1 (Sept. 20). 